\title{
Potential Earthquakes Rupturing the Chinshan and Shangjiao Faults in the Taipei Metropolitan Area
}

\author{
Jeen-Hwa Wang ${ }^{1, *}$ \\ ${ }^{1}$ Institute of Earth Sciences, Academia Sinica, Taipei, Taiwan, ROC \\ Received 8 January 2007, accepted 23 June 2007
}

\begin{abstract}
There are two active faults, i.e., the Chinshan and Shangjiao faults in the Taipei Metropolitan Area. The moment magnitude $(M)$, maximum displacement $\left(D_{\max }\right)$, and average displacement $\left(D_{\text {ave }}\right)$ of potential earthquakes, which would rupture the two faults, are evaluated. The fault lengths are 25 and $20 \mathrm{~km}$, respectively, for the Chinshan and Shangjiao faults. The optimum values of the three parameters are: (1) $\mathrm{M}=6.6, \mathrm{D}_{\max }=0.97 \mathrm{~m}$, and $\mathrm{D}_{\text {ave }}=0.42 \mathrm{~m}$ for the Shangjiao fault; and (2) $\mathrm{M}=6.7, \mathrm{D}_{\max }=1.35 \mathrm{~m}$, and $\mathrm{D}_{\text {ave }}=0.55 \mathrm{~m}$ for the Chinshan fault; and (3) $\mathrm{M}=7.0, \mathrm{D}_{\max }=3.28 \mathrm{~m}$, and $\mathrm{D}_{\text {ave }}=1.15 \mathrm{~m}$ for the Chinshan-Shangjiao fault system.
\end{abstract}

Key words: Potential earthquake, Moment magnitude, Maximum displacement, Average displacement

Citation: Wang, J. H., 2008: Potential earthquakes rupturing the Chinshan and Shangjiao faults in the Taipei Metropolitan Area. Terr. Atmos. Ocean. Sci., 19, 205-212, doi: 10.3319/TAO.2008.19.3.205(T)

\section{INTRODUCTION}

Taiwan is situated in the collision boundary between the Philippine Sea and Eurasian plates (Tsai et al. 1977; Wu 1978; Lin 2002). The former is moving northwestward with a speed of $8.2 \mathrm{~cm} \mathrm{yr}^{-1}$ (Yu et al. 1997) and colliding with the latter. The Philippine Sea plate subducts northern Taiwan. Northern Taiwan is the region where the Taipei Metropoli$\tan$ Area (TMA) is located. This collision causes a high degree of seismicity in the Taiwan region (Wang 1998). The TMA, including the City of Taipei and several satellite cities, is the political, economic, and cultural center of Taiwan. The greater Taipei region has a population of more than 4 million and rising. There are a large number of high-rise buildings, where many people live and/or work daily and in recent years a modern rapid transportation system has been constructed. In addition, two nuclear power plants located in the vicinity have been in operation since 1971. Consequently, the TMA must be the subject of much attention in terms of seismic risk mitigation.

There are several faults in the TMA (see Fig. 1). Those faults are quite important in terms of seismic hazard assessment in the TMA. Amongst these faults, two active faults,

\footnotetext{
* Corresponding author

E-mail:jhwang@earth.sinica.edu.tw
}

i.e., the Chinshan and Shangjiao faults, have long been assumed to be related to a large earthquake that resulted in the so-called Kangshi Taipei Lake. This event occurred in the Emperor Kangshi period of the Chin Dynasty in 1694 (Lin 1957; Hsu 1983b; Shieh 2000). Note the Shangjiao fault is also called the Sanchiao fault by some authors. In order to form an earthquake-induced lake, the average vertical displacement of the event would have needed to have been several meters. In order to explore this problem, two questions must first be answered. The first is to how large the largest earthquake to occur independently on either the Chinshan or Shangjiao fault could be. And the second is to whether the two faults could fail simultaneously, if they have different faulting mechanisms. In order to answer the second question, stress re-distribution on a fault caused by the failure of the other must be evaluated. This question will be studied in a separate article.

Shyu et al. (2005) studied the first question. They estimated the magnitudes of potential earthquakes, which would rupture 20 recognized active faults in and surrounding Taiwan by using the relationships of moment magnitude versus fault area inferred by Wells and Coppersmith (1994). Their estimated value for a potential earthquake rupturing the Chinshan-Shangiiao fault system, with a total length of $45 \mathrm{~km}$ and a fault width of $15 \mathrm{~km}$, is 6.9. The fault width 
used by them might be over-estimated, because the geotemperature below the two faults, especially for the Chinshan fault, is high as mentioned below.

In this study, an attempt is made to answer the first question from evaluations of the moment magnitude, maximum displacement, and average displacement of a potential earthquake that would rupture the Shangjiao fault, the Chinshan fault, or the Chinshan-Shangjiao fault system using the relationships between source parameters in terms of the surface fault (rupture) length inferred by Wells and Coppersmith (1994). The calculated results will be discussed in depth.

\section{THE TAIPEI METROPOLITAN AREA}

Figure 1 shows the geology of the TMA, situated in the Taipei Basin surrounded by the Tatun Volcano Group (TVG), Linkou Tableland, and the Western Foothills. The Taipei Basin, which lies on the Tertiary basement, is filled with Quaternary sediments (Wang-Lee and Lin 1987; Chang et al. 1998). The Quaternary sediments are composed of three formations, the Sungshan formation, the Chingmei formation, and the Hsinchuang formation from top to bottom. Teng et al. $(1994,1999)$ further divided the Hsinchuang formation into the Wuku formation and Panchiou formation. The topmost part of the Sungshan formation is a soft layer, composed of unconsolidated sand, silt and clay
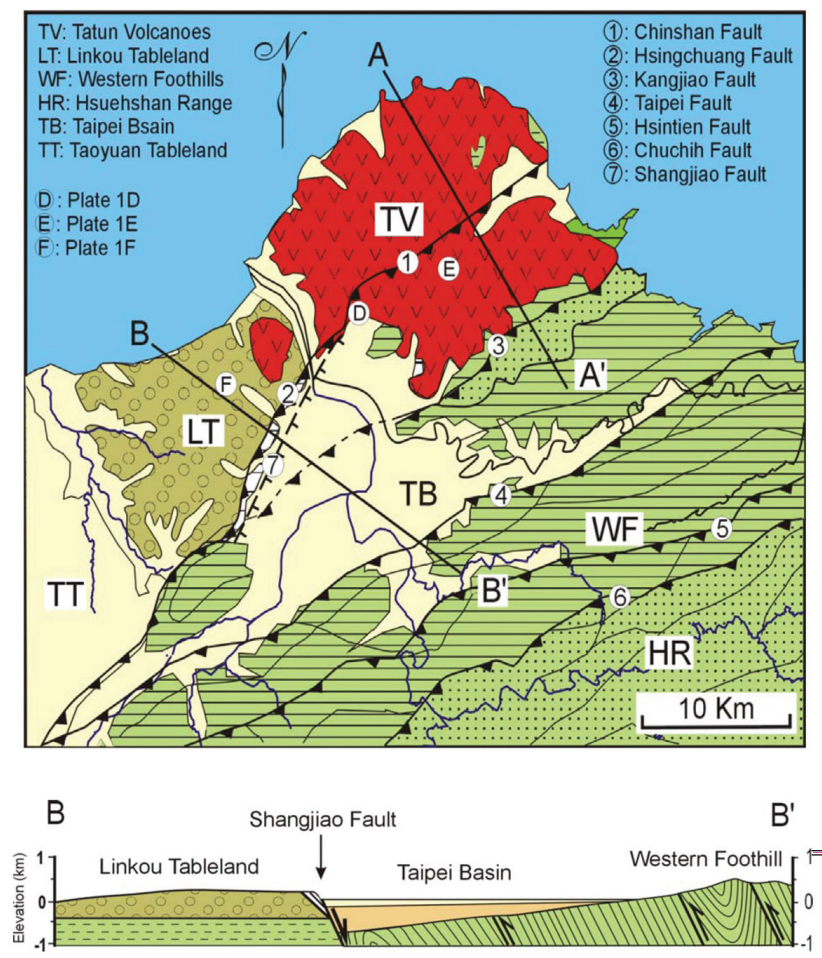

Fig. 1. Upper: geology map of the Taipei Metropolitan Area and surroundings (after Teng et al. 2001); Lower: geological profile along Line BB' shown in the upper diagram. with a thickness varying from $50 \mathrm{~m}$ in the southeastern part to $120 \mathrm{~m}$ in northwestern part. The Hsinchuang formation is composed of sand and silt. The lower part of the formation is dominated by silt. The Chingmei formation is full of gravel.

From the Pliocene to the Pleistocene, three main reverse faults have developed along the western boundary of the Western Foothills in this area. From NW to SE, the three faults are: the Hsinchuang fault, the Kanchiao fault, and the Taipei fault, all trending in the NE-SW direction. During this time period, the Linkou area was a delta fan at the foothills of the faults, where conglomerates were widely deposited. About 0.8 m.y. ago (cf. Teng 1996; Wang et al. 1999), the tectonic condition in northern Taiwan changed from compression to tension, which resulted in the formation of the TVG and normal faults. A segment of the Hsinchung fault (Wu 1965) re-activated as a normal fault. This segment is called the Shangjiao fault. This tension-type tectonics led to a pull-apart mechanism, which made the Taipei Basin subside (cf. Lee 1996; Lee et al. 1999). Thus, the deepest portion of the basin is along the NW border. This results in a half-bowl-shape basin, with the cut boundary right along the Shangjiao fault.

The basement is shallower than $250 \mathrm{~m}$ in the south and deeper than $500 \mathrm{~m}$ in the north. This might be caused by the formation of the Shangjiao fault. Bonilla (1977) proposed that the Shangjiao fault is quite young and moved in the near past. This means that this fault could be active in the future. The old Kanchiao fault uplifted in the basement, thus forming a geological boundary separating the basin into two parts, with different basement depths and deposits (cf. Lee 1996; Lee et al. 1999).

In order to study the slip rates of active faults in the TMA, a GPS array has been deployed in the area since 1992 (Yu 2000). During 1992 - 2000, small extension rates of $0.12-0.15 \mu$ strain $\mathrm{yr}^{-1}$ in the directions of azimuth $=270^{\circ}$ - $288^{\circ}$ in the vicinity of the Chinshan and Shangjiao faults were recorded. In northern Taiwan, the average principal strain rates are: an extension rate of $0.09 \mu$ strain $\mathrm{yr}^{-1}$ along the direction of azimuth $=289^{\circ}$, and a shortening rate of $0.05 \mu$ strain $\mathrm{yr}^{-1}$ along the direction of azimuth $=19^{\circ}$. In addition, no significant vertical movement on the Shangjiao fault and significant slip across the Chinshan fault were detected.

Yang and Chen (1989) applied the transient electricmagnetic (TEM) method to locate the Chinshan fault. They assumed that this fault could be still active, because of the presence of a fault within strata of Quaternary age. From the Bouguer anomaly profiles, Chen and Yeh (1991) and Chen et al. (1995) stated that the Chinshan fault is a thrust fault with a dipping angle of $55^{\circ}-60^{\circ}$. Chan et al. (2005a, b) constructed a digital elevation map (DEM) by using LIDAR. They recognized numerous normal faults in the TVG. These normal faults cut through lava flats with a few to sev- 
eral meters of offset, suggesting recent activity of the faults. They also assumed that one of the normal faults could be the northeasterly extension of the Shangjiao fault. Its surface trace is parallel and southeast to the Chinshan fault. The two faults merge together at a depth of about $300 \mathrm{~m}$. From the data obtained from a micro-earthquake survey in the Taipei Basin during the period 17 June to 20 September 2004, Chen et al. (2005) stated that seismicity on and around the Shangiiao fault was very low. From re-located earthquakes occurring underneath northern Taiwan during 1973 to 2003, Kim et al. (2005) reported a cluster of events below the Chinshan fault, and also stressed that clustered seismcity trends with inconsistent dipping directions are manifest, and, in particular, a dominant linear southeast dipping seismicity trend is readily identifiable. Their results show that the majority of focal mechanisms of earthquakes in the TVG exhibit normal faulting.

Although seismicity is low in the TMA, numerous earthquakes still occur near or in this area (Hsu 1961; Hsu 1983b; Wang 1998). The occurrence times, locations, magnitudes, and effects of a few $M>5$ earthquakes, which occurred in or near the area and caused destruction in the TMA, are given in Table 1. Errors in the magnitudes of earthquakes that occurred before 1900 are high. The 1694 event, which occurred in the Emperor Kangshi period of Chin Dynasty, was quantified to be 6.5 by Wu (1978) and 7 by Hsu (1983b). This event has long been assumed to have resulted in an earthquake-induced lake, i.e., the Kangshi Taipei Lake, and the destruction of aboriginal houses (Lin 1957; Hsu 1983a). Shyu et al. (2005) assumed the possibility of the lake being formed by the 1694 event. On the other hand, Lee et al. (1999) and Lin (2001) disagreed on the connection between the formation of the Kangshi Taipei Lake and the failure of the Shangjiao fault.

\section{THE POTENTIAL EVENTS}

In order to evaluate the magnitudes of potential earthquakes, which would rupture the Shangjiao and Chinshan faults, it is necessary to understand the seismogenic environments of the area. Wang (1988) calculated the b-values of the whole of Taiwan Island. He stated that the b-value is higher in northern Taiwan than in the remaining areas. This might be due to higher geo-temperature in northern Taiwan caused by past volcanic activities. Except for the earthquakes in the Wadati-Benioff subduction zone, the events occurring in northern Taiwan are usually shallow (Wang et al. 1994, 2006; Ma et al. 1996). Figure 2 shows the epicenters of $M \geq 4$ earthquakes during 1973 - 2005. Symbols are open and solid circles for shallow $(0-40 \mathrm{~km})$ and deep $(60-190 \mathrm{~km})$ events, respectively. It is clear that no $M \geq 4$ events were located around the Shangjiao fault and seismicity was low around the Chinshan fault. Wang et al. (2006) reported that the focal depths of $\mathrm{M} \geq 4$ earthquakes are less than $5 \mathrm{~km}$. From the micro-earthquakes that occurred in the Taipei Basin during the period 17 June to 20 September 2004, Chen et al. (2005) stated that seismicity on and around the Shangjiao fault is very low. After re-locating $M \geq 4$ earthquakes for the period 1973 - 2003, Kim et al. (2005) show that there was only one microearthquake, which occurred near the Shangjiao fault, and the focal depths of events below the Chinshan fault are mainly smaller than $10 \mathrm{~km}$, with the majority less than $5 \mathrm{~km}$. The depth profile of $\mathrm{M}<2.8$ microearthquakes recorded by a local temporary array between October 2003 and February 2005 by Konstantinou et al. (2007) displays all events having a focal depth less than $6 \mathrm{~km}$. All results suggest that the seismogenic zone (Scholz 1990) beneath the TVG has a thickness $<10 \mathrm{~km}$ and is thinner than its neighbors. Therefore, Shyu et al. (2005) over-estimated the fault width $(=15 \mathrm{~km})$ of the whole Chinshan-Shangjiao fault system. Since the fault width cannot be precisely determined due to incomplete information, the earthquake magnitude will be evaluated only on the basis of fault length in this study. Wang and $\mathrm{Ou}(1998)$ stressed that the main factor in controlling the displacement is the fault length rather than the fault width. Hence, Eqs. (1) - (6), which are a function of surface fault length only, can be applied here to calculate $\mathrm{M}$, $\mathrm{D}_{\max }$, and $\mathrm{D}_{\text {ave }}$ of the two faults.

Table 1. The $M>5$ destructive earthquakes occurred in or near the area.

\begin{tabular}{|c|c|c|c|}
\hline Time & Location & $\mathbf{M}$ & Effects \\
\hline $1694 / 4-5$ & Near Taipei & 7 & Kanshi Lake and damaged houses \\
\hline $1815 / 7 / 11$ & Near Taipei & 6.5 & Minor damages \\
\hline $1867 / 12 / 18$ & Offshore Keelung & 7 & $\begin{array}{l}\text { Tsunami } \\
\text { Surface ruptures death }\end{array}$ \\
\hline $1909 / 04 / 15$ & $25^{\circ} \mathrm{N}, 121.5^{\circ} \mathrm{E}$ (focal depth $\left.=80 \mathrm{~km}\right)$ & 7.3 & $\begin{array}{l}\text { Death: 9; Injured: } 51 \\
\text { Houses: Collapsed: } 122 \\
\text { Damaged: } 1050\end{array}$ \\
\hline $1988 / 07 / 03$ & $25.16^{\circ} \mathrm{N}, 121.57^{\circ} \mathrm{E}($ focal depth $=5 \mathrm{~km})$ & 5.3 & Injured: 16 \\
\hline
\end{tabular}




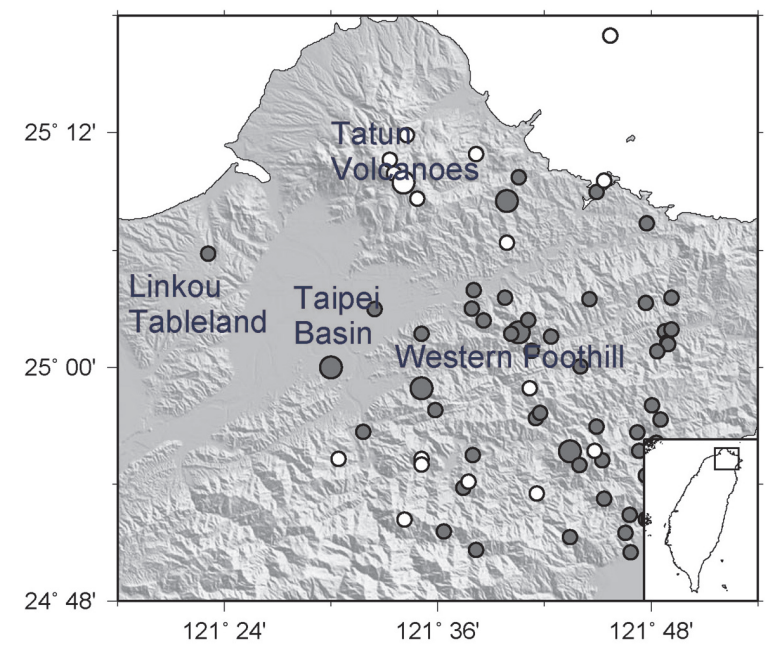

Fig. 2. Epicenters of $M \geq 4$ earthquakes for 1973 - 2005: open and solid circles for shallow $(0-40 \mathrm{~km})$ and deep $(60-190 \mathrm{~km})$ events, respectively (after Wang et al. 2006).

The Chinshan fault has been long assumed to be a thrust fault. Since $\sim 2.8 \mathrm{Ma}$ ago, northern Taiwan has been changed from compression to extension (cf. Teng 1996; Wang et al. 1999). This suggests a low possibility of the occurrence of thrust faulting along the Chinshan fault. Huang (2003) assumed the Shangjiao fault extends northeastward to the Chinshan area. Lee (1993) assumed that the Chinshan fault has shown normal faulting since late Pleistocence. Chan et al. (2005) constructed a digital elevation map (DEM) using LIDAR. Their results show the existence of a normal fault system in the TVG. These normal faults cut through lava flats with a few to several meters of offset, thus suggesting recent activity along the faults. Therefore, in the case that the Chinshan fault is still a thrust fault, it should have been inactive since $\sim 2.8 \mathrm{Ma}$ ago and, thus, can be classified as an inactive fault. On the other hand, in the case that this fault could be active in the future, it should behave like a normal fault, because the regional tectonic environment has changed. Hence, the moment magnitude of this fault will be evaluated by assuming that it is a normal fault. For the purposes of comparison, the moment magnitude relating to a thrust-type Chinshan fault will also be estimated.

For global earthquakes, Wells and Coppersmith (1994) inferred the following relationships for moment magnitude (M), which is essentially the surface-wave magnitude when $\mathrm{M}<8$, maximum displacement $\left(\mathrm{D}_{\max }\right)$, and average displacement $\left(D_{\text {ave }}\right)$ in terms of surface fault (rupture) length $(L)$ :

\section{(A) For a Normal Fault:}

The Moment Magnitude (M):

$\mathrm{M}=(4.86 \pm 0.34)+(1.32 \pm 0.26) \times \log (\mathrm{L})$
The Maximum Displacement $\left(D_{\max }\right)$ :

$\log \left(\mathrm{D}_{\max }\right)=(-1.98 \pm 0.50)+(1.51 \pm 0.35) \times \log (\mathrm{L})$

The Average Displacement $\left(D_{\text {ave }}\right)$ :

$\log \left(\mathrm{D}_{\text {ave }}\right)=(-1.99 \pm 0.72)+(1.24 \pm 0.49) \times \log (\mathrm{L})$

\section{(B) For a Thrust Fault:}

The Moment Magnitude (M):

$\mathrm{M}=(5.00 \pm 0.22)+(1.22 \pm 0.16) \times \log (\mathrm{L})$

The Maximum Displacement $\left(D_{\max }\right)$ :

$\log \left(\mathrm{D}_{\text {max }}\right)=(-0.44 \pm 0.34)+(0.42 \pm 0.23) \times \log (\mathrm{L})$

The Average Displacement $\left(D_{\text {ave }}\right)$ :

$\log \left(\mathrm{D}_{\text {ave }}\right)=(-0.60 \pm 0.39)+(0.31 \pm 0.27) \times \log (\mathrm{L})$

The surface lengths of the Shangjiao fault, Chinshan fault, and Chinshan-Shangjiao fault system are, respectively, 20, 25, and $45 \mathrm{~km}$ (Shyu et al. 2005). As mentioned above, the Shangjiao fault is normal faulting, while the Chinshan fault could be either thrust or normal faulting. Hence, there are two scenarios for the Chinshan fault: Case 1 for normal faulting and Case 2 for thrust faulting. The calculated results are shown below:

\section{(A) For the Shangjiao Fault}

From Eq. (1), the moment magnitude is $5.9 \leqq \mathrm{M} \leqq$ 7.3 , with an optimum value of 6.6. From Eq. (2), the maximum displacement is $0.11 \mathrm{~m} \leqq \mathrm{D}_{\max } \leqq 8.71 \mathrm{~m}$, with an optimum value of $0.97 \mathrm{~m}$. From Eq. (3), the average displacement is $0.02 \mathrm{~m} \leqq \mathrm{D}_{\text {ave }} \leqq 9.57 \mathrm{~m}$, with an optimum value of $0.42 \mathrm{~m}$.

\section{(B) For the Chinshan Fault}

Case 1 for normal faulting:

From Eq. (1), the moment magnitude is $6.0 \leqq M \leqq$ 7.4, with an optimum value of 6.7. From Eq. (2), the maximum displacement is $0.14 \mathrm{~m} \leqq \mathrm{D}_{\max } \leqq 13.19 \mathrm{~m}$, with an optimum value of $1.35 \mathrm{~m}$. From Eq. (3), the average dis- 
placement is $0.02 \mathrm{~m} \leqq \mathrm{D}_{\text {ave }} \leqq 13.63 \mathrm{~m}$, with an optimum value of $0.55 \mathrm{~m}$.

\section{Case 2 for thrust faulting:}

From Eq. (4), the moment magnitude is $6.3 \leqq \mathrm{M} \leqq$ 7.2, with an optimum value of 6.7. From Eq. (5), the maximum displacement is $0.31 \mathrm{~m} \leqq \mathrm{D}_{\max } \leqq 6.44 \mathrm{~m}$, with an optimum value of $1.40 \mathrm{~m}$. From Eq. (6), the average displacement is $0.12 \mathrm{~m} \leqq \mathrm{D}_{\text {ave }} \leqq 3.99 \mathrm{~m}$, with an optimum value of $0.68 \mathrm{~m}$.

\section{(C) For the Chinshan-Shangjiao Fault System}

\section{Case 1 for a normal Chinshan fault:}

As mentioned above, Chan et al. (2005a, b) assumed the possible northeasterly extension of Shangjiao fault. Hence, a normal fault to include the two faults could be ruptured in the future and, thus, must also be taken into account. This fault is essentially similar to that shown in Shyu et al. (2005). Although the parts of the two faults below $300 \mathrm{~m}$ might merge together, the Chinshan-Shangjiao fault system rather than the Chinshan or Shangjiao fault is used to represent the whole fault system hereafter. Since the two faults have the same faulting type, the total length is just the sum of the individual fault lengths. This leads to $\mathrm{L}=45 \mathrm{~km}$. From Eq. (1), the moment magnitude is $6.3 \leqq \mathrm{M} \leqq 7.8$, with an optimum value of 7.0. From Eq. (2), the maximum displacement is $0.27 \mathrm{~m} \leqq \mathrm{D}_{\max } \leqq 39.35 \mathrm{~m}$, with an optimum value of $3.28 \mathrm{~m}$. From Eq. (3), the average displacement is $0.03 \mathrm{~m}$ $\leqq \mathrm{D}_{\text {ave }} \leqq 38.91 \mathrm{~m}$, with an optimum value of $1.15 \mathrm{~m}$.

\section{Case 2 for a thrust Chinshan fault:}

Since the faulting types of the two faults are different, it is better to calculate the value of $\mathrm{M}$ of the fault system from the sum of seismic radiation energies generated by the two faults than directly from the mean of the magnitudes. The seismic radiation energy, $\mathrm{E}_{\mathrm{s}}$, relates to the surface- wave magnitude in the Gutenberg-Richter's energy-magnitude law (Gutenberg and Richter 1956): $\log \left(\mathrm{E}_{\mathrm{s}}\right)=1.5 \mathrm{M}+11.8$

This formula also holds for the moment magnitude.

From Eq. (7), the value of $\mathrm{E}_{\mathrm{s}}$ of the Chinshan-Shangjiao fault system is $0.196 \times 10^{22} \mathrm{erg} \leqq \mathrm{E}_{\mathrm{s}} \leqq 8.247 \times 10^{22} \mathrm{erg}$, with the optimum value of $1.200 \times 10^{22} \mathrm{erg}$. Hence, the moment magnitude of the fault system is $6.3 \leqq M \leqq 7.4$, with an optimum value of 6.9. The maximum displacement can be the extreme values of the two faults, i.e., $0.11 \mathrm{~m} \leqq \mathrm{D}_{\max }$ $\leqq 8.71 \mathrm{~m}$, with an optimum value of $0.97 \mathrm{~m}$. The average displacement is the mean of the individual average values of the two faults, i.e., $0.07 \mathrm{~m} \leqq \mathrm{D}_{\text {ave }} \leqq 6.78 \mathrm{~m}$, with an optimum value of $0.55 \mathrm{~m}$.

The ranges and optimum values of moment magnitude, maximum displacement, and average displacement for the Shangjiao fault, Chinshan fault, and the Chinshan-Shangjiao fault system are displayed in Table 2.

\section{DISCUSSION}

Table 2 shows that the upper-bound moment magnitudes for all cases are larger than 7. However, this value might be over-estimated due to large standard deviations of Eqs. (1) and (4). This can also be seen from the inconsistence of evaluated values of $\mathrm{D}_{\max }$ and $\mathrm{D}_{\text {ave }}$. In general, the average displacement must be smaller than the maximum displacement. Now, the upper bound of $\mathrm{D}_{\text {ave }}$ is larger than that of $\mathrm{D}_{\max }$ for all cases. This is unreasonable and might be due to low reliability for the upper bounds of the two parameters. From Table 1 in Wells and Coppersmith (1994), for $\mathrm{L}=15 \pm 2 \mathrm{~km}$ the moment magnitude ranges from 6.3 - 7.28 for six normal-faulting earthquakes and 6.9 for one thrust-faulting event. There are two events with $\mathrm{M} \geq 7$ : The first one is the 3 January 1915 Avezzano, Italy, earthquake with $\mathrm{M}=7.0$ for $\mathrm{L}=20 \mathrm{~km}$ and the other the 10 November 1946 Ancash, Peru, earthquake with $\mathrm{M}=7.28$ for $\mathrm{L}=21 \mathrm{~km}$. However, the subsurface fault lengths inferred from seismic and geodetic data are 24 and $28 \mathrm{~km}$, respectively, for the former and the latter. This means that the real rupture length

Table 2. The ranges of magnitude, maximum displacement, and average displacement for the Shangjiao fault, Chinshan fault, and the ChinshanShangjiao fault system. The value shown in the parenthesis is the optimum one.

\begin{tabular}{llll}
\hline \multicolumn{1}{c}{ Fault } & \multicolumn{1}{c}{ M } & \multicolumn{1}{c}{$\mathbf{D}_{\text {max }}$} & \multicolumn{1}{c}{$\mathbf{D}_{\text {ave }}$} \\
\hline Shangjiao Fault & $5.9-7.3(6.6)$ & $0.11-8.71 \mathrm{~m}(0.97 \mathrm{~m})$ & $0.0-9.57 \mathrm{~m}(0.42 \mathrm{~m})$ \\
Chinshan Fault (Normal) & $6.0-7.4(6.7)$ & $0.14-13.69 \mathrm{~m}(1.35 \mathrm{~m})$ & $0.02-14.07 \mathrm{~m}(0.55 \mathrm{~m})$ \\
Chinshan Fault (Thrust) & $6.3-7.2(6.7)$ & $0.31-6.44 \mathrm{~m}(1.40 \mathrm{~m})$ & $0.12-3.99 \mathrm{~m}(0.68 \mathrm{~m})$ \\
Shangjiao Fault + Normal Chinshan Fault & $6.3-7.8(7.0)$ & $0.27-39.35 \mathrm{~m}(3.28 \mathrm{~m})$ & $0.03-38.91 \mathrm{~m}(1.15 \mathrm{~m})$ \\
Shangjiao Fault + Thrust Chinshan Fault & $6.3-7.4(6.9)$ & $0.11-8.71 \mathrm{~m}(0.97 \mathrm{~m})$ & $0.07-6.78 \mathrm{~m}(0.55 \mathrm{~m})$ \\
\hline
\end{tabular}


is longer than the observed surface rupture length or surface rupture was not completely observed in field surveys. The length of the Shangjiao fault is well determined, because its two ends are quite clear. Hence, the moment magnitude of a potential earthquake rupturing this fault should be smaller than 7 . There is only one thrust-faulting earthquake with 6.9 for $\mathrm{L}=22 \mathrm{~km}$ in Wells and Coppersmith (1994). Although a further comparison cannot be made, there is not any inconsistency between this study and theirs. For $\mathrm{L}=25 \pm 2 \mathrm{~km}$, the moment magnitude ranges from 6.6 - 6.8 for three thrustfaulting earthquakes and 7.6 for one normal-faulting event in Wells and Coppersmith (1994). For thrust faulting, it is appropriate to take 6.7 to be the moment magnitude for the Chinshan fault. The normal-faulting event listed in Wells and Coppersmith (1994) is the 8 November 1959 Hebgen Lake, USA, earthquake with $\mathrm{M}=7.6$ for $\mathrm{L}=26.5 \mathrm{~km}$. However, its subsurface fault length inferred from seismic data is $45 \mathrm{~km}$. Although the surface rupture length of the Chinshan fault cannot be well determined, the value of $\mathrm{L}=25 \mathrm{~km}$ seems to be an acceptable upper bound. Hence, the moment magnitude of a potential earthquake rupturing this fault should be smaller than 7. Since there is no normal-faulting event with $\mathrm{L}=45 \pm 2 \mathrm{~km}$ in Wells and Coppersmith (1994), a further comparison cannot be made. In addition, the number of data with $\mathrm{L}>40 \mathrm{~km}$ is small in their data set. Hence, uncertainty should be higher for longer faults than for shorter ones.

From the above discussion, we may conclude that the moment magnitude of the potential earthquake rupturing only either the Shangjiao fault or the Chinshan fault is smaller than 7 and can be up to 7 when the two faults break simultaneously. Comparison of evaluated values in this study and the observed ones in Wells and Coppersmith (1994) suggests that the maximum possible values for the three parameters are: (1) $\mathrm{M}=6.6, \mathrm{D}_{\max }=0.97 \mathrm{~m}$, and $\mathrm{D}_{\text {ave }}=$ $0.42 \mathrm{~m}$ for the Shangjiao fault; and (2) $\mathrm{M}=6.7, \mathrm{D}_{\max }=1.35$ $\mathrm{m}$, and $\mathrm{D}_{\text {ave }}=0.55 \mathrm{~m}$ for the Chinshan fault; and (3) $\mathrm{M}=7.0$, $D_{\max }=3.28 \mathrm{~m}$, and $\mathrm{D}_{\text {ave }}=1.15 \mathrm{~m}$ for the Chinshan-Shangjiao fault system. It is clear that for the Chinshan fault, $D_{\max }$ and $D_{\text {ave }}$ are larger for thrust faulting than for normal faulting, even though the values of $\mathrm{M}$ are the same for the two cases. For the Chinshan-Shangjiao fault system, $\mathrm{M}, \mathrm{D}_{\max }$, and $\mathrm{D}_{\text {ave }}$ are all greater for a thrust Shangjiao fault than a normal one. Meanwhile, the value of $\mathrm{M}$ for this fault system is only slightly larger than that estimated by Shyu et al. (2005).

The southern end of the Chinshan fault touches the Taipei Basin. At the two ends of a fault the displacements are usually small (cf. Scholz 1990). Hence, the Kangshi Taipei Lake might not be induced by rupture of the Chinshan fault. On the other hand, the upper bound of $\mathrm{D}_{\max }$ for the Shangjiao fault is only $0.97 \mathrm{~m}$. This does not seem able to cause an observable lake, because the depth, with a maximum value of $0.97 \mathrm{~m}$ on the fault, of subsidence of the ground surface decreases with the distance from the surface trace of the fault. If the Chinshan-Shangjiao fault system, with a normal Chinshan fault, breaks, it would be possible to produce a small-scaled, shallow pond, because of $\mathrm{D}_{\text {ave }}=$ $1.15 \mathrm{~m}$ and $\mathrm{D}_{\max }=3.28 \mathrm{~m}$. However, since the Chinshan fault was not active in the past $2.8 \mathrm{Ma}$ as mentioned above, the possibility of forming the Kangshi Taipei Lake by the 1694 event is very low.

\section{SUMMARY}

The possible values for the moment magnitude (M), maximum displacement $\left(\mathrm{D}_{\max }\right)$, and average displacement $\left(D_{\text {ave }}\right)$ for the Shangjiao fault, the Chinshan fault, and the Chinshan- Shangjiao fault system are evaluated from the relationships of the three parameters in terms of fault length (Wells and Coppersmith 1994). The optimum values for the Shangjiao fault are: $M=6.6, D_{\max }=0.97 \mathrm{~m}$, and $\mathrm{D}_{\text {ave }}=0.42 \mathrm{~m}$. The optimum values for the Chinshan fault are: (1) $M=6.7$, $\mathrm{D}_{\max }=1.35 \mathrm{~m}$, and $\mathrm{D}_{\text {ave }}=0.5 \mathrm{~m}$ for Case 1 ; and (2) $\mathrm{M}=6.7$, $\mathrm{D}_{\max }=1.40 \mathrm{~m}$, and $\mathrm{D}_{\text {ave }}=0.68 \mathrm{~m}$ for Case 2 . The optimum values for the Chinshan-Shangiiao fault system are: (1) $\mathrm{M}=$ $7.0, \mathrm{D}_{\max }=3.28 \mathrm{~m}$, and $\mathrm{D}_{\mathrm{ave}}=1.15 \mathrm{~m}$ for Case 1 ; and (1) $\mathrm{M}=6.9, \mathrm{D}_{\max }=0.97 \mathrm{~m}$, and $\mathrm{D}_{\text {ave }}=0.55 \mathrm{~m}$ for Case 2 . The moment magnitude is smaller than 7.0 when the two faults break individually and can be up to 7.0 when they fail simultaneously. Since the optimum values of average displacement for all cases in consideration are less than $1.2 \mathrm{~m}$, it does not seem possible to produce an earthquake-induced lake, like the Kangshi Taipei Lake.

Acknowledgments The authors would like to express their thanks to two anonymous reviewers for valuable comments. This study was sponsored by Academia Sinica (Taipei) under Grant No. AS-94-TP-A08.

\section{REFERENCES}

Bonilla, M. G., 1977: Summary of Quarternary faulting and elevation changes in Taiwan. Mem. Geol. Soc. China, 2, 43-46.

Chan, Y. C., J. C. Lee, J. K. Liu, and D. Y. Cheng, 2005a: Acquisition of High-Resolution Digital Elevation Model Using Airborne LIDAR Technique and Its Application to Active Geomorphology in the Taipei Metropolitan Area (1/3). Central Geol. Surv., MOEA, ROC, 143 pp. (in Chinese)

Chan, Y. C., J. C. Lee, R. F. Chen, K. C. Chang, J. K. Liu, W. C. Hsu, J. C. Hu, W. S. Chen, C. C. Yang, Y. G. Chen, D. Y. Cheng, S. Tsao, and Y. C. Hsieh, 2005b: Airborne LIDAR mapping of the metropolitan Taipei area: Current status and progress. Proc. Symp. on Volcanic Activity and the Sanchiao Fault, Central Geol. Surv., MOEA, ROC, 87-101. (in Chinese)

Chang, H. C., C. W. Lin, M. M. Chen, and S. T. Lu, 1998: 
An Introduction to the Active Faults of Taiwan, Explanatory Text of the Active Fault Map of Taiwan SCALE 1 : 55000. Central Geol. Surv., MOEA, ROC, 103 pp. (in Chinese)

Chen, K. C., B. S. Huang, and W. G. Huang, 2005: Seismicity in the Taipei Basin and surroundings. Proc. Symp. on Volcanic Activity and the Shanchiao Fault, Central Geol. Surv., MOEA, ROC, 11-15. (in Chinese)

Chen, K. J. and Y. H. Yeh, 1991: Gravity and microearthquakes studies in the Chinshan-Tanshui area, northern Taiwan. Terr. Atmos. Ocean. Sci., 2, 35-50.

Chen, K. J., Y. H. Yeh, H. Y. Yen, and C. H. Lin, 1995: Seismological studies in the Chinshan fault area. $J$. Geol. Soc. China, 38, 335-352.

Gutenberg, B. and C. F. Richter, 1956: Earth magnitude, intensity, energy and acceleration. Bull. Seismol Soc. Am., 46, 105-145.

Hsu, H., 1983a: Source materials on the history of natural disasters in Ching Taiwan. Hazards Mitigation S \& T Report., 72-01, 5-6. (in Chinese)

Hsu, M. T., 1961: Seismicity of Taiwan (Formosa). Bull. Earthquake Res. Inst., Tokyo Univ., 39, 831-847.

Hsu, M. T., 1983b: Estimation of earthquake magnitudes and seismic intensities of destructive earthquakes in the Ming and Ching Eras. Meteorol. Bull., CWB, 29, 1-18. (in Chinese)

Huang, S. Y., 2003: Prehistoric earthquakes along the Shanchiao fault, Taipei Basin, northern Taiwan. Master Thesis, Graduate Faculty, Central Washington University, 83 pp. (in Chinese)

Kim, K. H., C. H. Chang, K. F. Ma, J. M. Chiu, and K. C. Chen, 2005: Modern seismic observations in the Tatun volcano region of northern Taiwan: Seismic/volcanic hazard adjacent to the Taipei Metropolitan area. Terr. Atmos. Ocean. Sci., 16, 579-594.

Konstantinou, K. I., C. H. Lin, and W. T. Liang, 2007: Seismicity characteristics of a potentially active Quaternary volcano: The Tatun Volcano Group, northern Taiwan. J. Volcanol. Geothermal Res., 160, 300-318, doi: 10.1016/j.jvolgeores.2006.09.009.

Lee, C. T., 1993: Assessment of activity of the ChinshanShangjiao fault. Proc. Symp. Appl. Engineer. Geol. Tech. V, 153-172. (in Chinese)

Lee, J. F., 1996: A fault wedge structure - Concerning the formation of Taipei Basin, Abstract of $30^{\text {th }}$ Intl. Geol. Congr., 1, Beijing, PRC, 4-14.

Lee, J. F., C. C. Lin, D. C. Lai, T. W. Su, Z. L. Chiu, and C. J. Zeng, 1999: The study of the formation of Taipei Basin. Centr. Geol. Surv. Spec. Pub., 11, 207-226. (in Chinese)

Lin, C. H., 2002: Active continental subduction and crustal exhumation: The Taiwan orogeny. Terr. Nova, 14, 281-287.

Lin, C. H., K. I. Konstantinou, W. T. Liang, H. C. Pu, Y.
M. Lin, S. H. You, and Y. P. Huang, 2005: Preliminary analysis of volcanoseismic signals recorded at the Tatun Volcano Group, northern Taiwan. Geophys. Res. Lett., 32, L10313, doi: 10.1029/2005GL022861.

Lin, C. S., 1957: Topography of Taiwan. Committee of Documentation, Taiwan Province, 303-314. (in Chinese)

Lin, C. T., 2001: Geological environment of the Taipei metropolitan area. Proceed. Sympo. Geol. Hazards in the Taipei Metropolitan Area, 1.1-1.99. (in Chinese)

Ma, K. F., J. H. Wang, and D. Zhao, 1996: Three-dimensional seismic velocity structure of the crustal and uppermost mantle beneath Taiwan. J. Phys. Earth, 44, 85-105.

Scholz, G. H., 1990: The Mechanics of Earthquakes and Faulting. Cambridge Univ. Press, 439 pp.

Shieh, Y. T., 2000: The paleogeograph of the ancient Taipei lakebed in the Kangshi period. J. Geogr. Sci., 27, 85-95. (in Chinese)

Shyu, J. B. H., K. Sieh, Y. G. Chen, and C. S. Liu, 2005: Neotectonic architecture of Taiwan and its implications for future large earthquakes. J. Geophys. Res., 110, B08402, doi: 10.1029/2004JB003251.

Teng, L. S., 1996: Extension collapse of the northern Taiwan mountain belt. Geology, 24, 949-952.

Teng, L. S., S. C. Wang, C. B. Chang, C. Hsu, P. B. Yuan, and P. Y., Chen, 1994: Quaternary strata frame of the Taipei basin. Proc. Joint Symp. on Taiwan Quaternary (5) and on Investi. of Subsurface Geology/Engineer. Environ. of Taipei Basin, 129-135. (in Chinese)

Teng, L. S., P. B. Yuan, P. Y. Chen, C. H. Peng, T. C. Lai, L. Y. Fei, and H. J. Liu, 1999: Lithostratigraphy of Taipei Basin deposits. Centr. Geol. Surv. Spec. Pub., 11, 41-66. (in Chinese)

Teng, L. S., C. T. Lee, C. H. Peng, W. F. Chen, and C. J. Chu, 2001: Origin and geological evolution of the Taipei Basin, Northern Taiwan. West. Pac. Earth Sci., 1, 115-142.

Tsai, Y. B., T. L. Teng, J. M. Chiu, and H. L. Liu, 1977: Tectonic implications of the seismicity in the Taiwan region. Memoir. Geol. Soc. China, 2, 13-41.

Wang, J. H., 1988: b values of shallow earthquakes in Taiwan. Bull. Seismol. Soc. Am., 78, 1243-1254.

Wang, J. H., 1998: Studies of earthquake seismology in Taiwan during the 1897 - 1996 period. J. Geol. Soc. China, 41, 291-336.

Wang, J. H. and S. S. Ou, 1998: On scaling of earthquake faults. Bull. Seismol. Soc. Am., 88, 758-765.

Wang, J. H., K. C. Chen, and T. Q. Lee, 1994: Depth distribution of shallow earthquakes in Taiwan. J. Geol. Soc. China, 37, 125-142.

Wang, J. H., M. W. Huang, and W. G. Huang, 2006: Aspects of $M \geq 4$ earthquakes in the Taipei metropolitan area. West. Pac. Earth Sci., 6, 169-190. 
Wang, K. L., S. L. Chung, C. H. Chen, R. Shinjo, T. F. Yang, and C. H. Chen, 1999: Post-collisional magmatism around northern Taiwan and its relation with opening of the Okinawa trough. Tectonophysics, $\mathbf{3 0 8}$, 363-376.

Wang-Lee, C. M. and T. P. Lin, 1987: The geology and land subsidence of the Taipei Basin. Memoir Geol. Soc. China, 9, 447-464.

Wells, D. L. and K. J. Coppersmith, 1994: New empirical relationships among magnitude, rupture length, rupture width, and surface displacement. Bull. Seismol. Soc. Am., 84, 974-1002.

Wu, F. T., 1965: Subsurface geology of the Hsinchuang structure in the Taipei Basin. Petrol. Geol. Taiwan, $\mathbf{4}$, 271-282.

Wu, F. T., 1978: Recent tectonics of Taiwan. J. Phys. Earth, 2 (Suppl.), S265-S299.

Yang, C. H. and C. S. Chen, 1989: Application of the TEM method in the Chinshan fault area, Chinshan, Taiwan. Proc. Geol. Soc. China, 32, 369-381.

Yu, S. B., 2000: Geodetic surveys for active faults and subsidence. Open-file Rept., Central Geol. Suv., 89 pp. (in Chinese)

Yu, S. B., H. Y. Chen, L. C. Kuo, S. E. Lallemand, and H. H. Tsien, 1997: Velocity field of GPS stations in the Taiwan area. Tectonophysics, 274, 41-59. 